\title{
The Election Silence in contemporary democracies. Questions about the sense of election silence in the Age of Internet ${ }^{1}$
}

\begin{abstract}
Information and Communication Technologies impact the democratic institutions and procedures to a great extent. One of examples of mechanisms affected by the use of ICT is so called election silence. The idea of election silence to provide voters with a peaceful, free from political agitation, conditions to consider and make final decision on elections. Despite the ban on campaigning during the election silence, many Internet users campaign for politicians or political parties, violating the existing law. The main aim of this article is to answer the questions about the ways of breaking the pre-election silence and about sense of this mechanism in the Internet age. The motivation to focus on this topic was the appearance of both: a large number of media reports on political agitation in the Internet and doubts about the continuing sense of functioning of the election silence.
\end{abstract}

Key words: election silence, Internet, agitation, campaign, violation of the election silence

$\mathbf{T}$ he role of Information and Communication Technologies is constantly growing. Modern technologies find their applications in all aspects of modern human life, and also as tools for exercising democratic power.

In times of the rapid development of new technologies the democracy also has been changing. Information and Communication Technologies impact the democratic institutions to a great extent. The evidence for this is the emergence of the term "electronic democracy" (e-democracy) in political science literature (Hacker, Dijk 2000, p. 19). E-democracy represents the use of information and communication technologies (ICTs) and computer mediated communication (CMC) in all kinds of media (e.g. the Internet, interactive broadcasting and digital telephony) for purposes of enhancing political democracy or the participation of citizens in democratic communication.

A number of scholars endorse the view that ICTs such as the Internet, can stimulate systematic improvement of democracy in young democracies and rapid democratization in regions of the world where democracy has not been adopted yet (Ferdinand, 2000, p. 3). What's more, in developed democracies, parliaments use information and communication technologies (ICTs) to modernize decision processes and to communicate with the electorate and the world. Without any doubt one may state that "recently, both developing and developed countries have promoted the use of ICTs in democratic processes

${ }^{1}$ This article presents part of the research results published in: M. Musiał-Karg, Cisza wyborcza $w$ dobie Internetu, "Przegląd Sejmowy" 2013, no. 3(116) and M. Musiał-Karg, Cisza wyborcza w internecie-przyklad polskich wyborów parlamentarnych z 2011 r., "Studia Politologiczne" 2013, no. 27. 
because they enhance the free flow of information, ideas and knowledge" (Kanyo, 2012, p. 312). Politicians in many states treat tools of modern technologies as a solutions for improving democracy, decision-making processes and as a panacea for the low participation rate in popular elections. It seems that the political actors themselves are curious about the applications of ICT and they have already appreciated benefits of the new techniques that facilitate their political duties, responsibilities and relations with voters. Additionally, parliaments, governments and subordinate offices have changed and they are still changing the way how they function by informing society and communicating with people through new channels. The reason for this is the fact that the "ICTs have changed the way information is gathered, stored, processed and disseminated" (Kanyo, 2012, p. 312). Also, the electorate seems to be taking greater notice of the benefits drawn from the application of ICT - particularly during the election campaigns and during the popular votes.

In many contemporary democracies one of the very important aspect of popular votes is election silence. Election silence, sometimes also called pre-election silence (electoral silence, campaign silence) is a specific legal time, which usually begins just before the voting day and ends at the end of voting (Michalak, Sokala, 2010, p. 20). In practice it is a ban on political campaigning prior to a presidential, parliamentary and local election or referendum. In many countries it is understood as a restriction of freedom of speech. This is a reason why election silence is considered unconstitutional in many Western democracies. Election silence is, however, quite common in young democracies. The political agitation in the internet is also forbidden during the election silence. Thus, in the context of the subject matter of this text, there appears a question relating to the legitimacy of the operation of silence in a situation where on the Internet, e.g. on Polish-language web pages located on foreign servers, electoral campaigning can be carried out and foreign portals can announce election surveys results. That is why the main aim of this article is to answer the questions about the sense of election silence in the era of new media (especially the Internet) and about the violations of election silence in the Internet. To answer the research questions the following methods have been applied: the legal-institutional analysis that helped to overview the national constitutions and other legal acts, and to see where and how the elections silence takes effect in legal context. Thanks to comparative approach the author could notice the similarities and differences in the functioning of the election silence in various countries of Central and Eastern Europe. In the empirical part - devoted to the practical dimension of election silence in Poland in the age of the Internet - the author analyzed fragments of political blogs and websites of information services and social networks. The aim of such procedure was to present examples and methods of violations of election silence on the Internet. The motivation to focus on this topic was the appearance of both: a large number of media reports on political agitation in the Internet and doubts about the continuing sense of functioning of the election silence. Some examples from Polish political campaigns will be used in this text.

\section{Election silence}

The essence of election silence is to give voters a peaceful (free from political agitation) conditions to consider and make final decision on elections. Election silence has 
been introduced in order to help voters in making reasonable choice and allow them for appropriate, that is quiet, without trying to influence them by individual electoral committees, conditions to decide on election. Voters should evaluate calmly the political offer, give it a careful consideration, rethink their decision in conditions which are free of electioneering. The assumption of election silence is to provide a chance for reflection and deliberation on whom to vote in the election.

The election silence (pre-electoral silence, campaign silence) is a period of time, when it is prohibited to conduct electioneering. Most of legislations concerning the process of election establishes "electoral day silence" (only during the voting day). In some countries of the pre-election silence begins earlier, usually 24 hours before opening the polls (Wiszowaty, 2012, p. 7). An election silence serves in some countries as a special time given to allow a "cooling-off" period for voters. As it was emphasized - during this time no active campaigning is allowed, but usually informing about the opinion polls is also banned. The silence is generally legally enforced, though in some countries it is just a "gentlemen's agreement" between leading parties or a "this is how it has always been done" agreement, between parties, to guide them in terms of how they can and should campaign (Campaign silence...). The are penalties for breaking the law on election silence, usually a fine.

Indeed, it is very interesting that, due to the phenomenon's lack of observation in English-speaking countries, there does not exist any phrase commonly used in English to describe this silence. This device is however used in many of the world's democracies "in order to balance out the campaigning and maintain a free voting environment" ( $\mathrm{Cam}$ paign silence...).

However, in many countries, the election campaign does not last until the "last moment", that is, until the day of voting. Similarly as in Poland, they adopted the solution of election silence, during which it is prohibited to carry out any agitation in favor of competing political forces (Kryszeń 2007, p. 185). Election silences are observed in the following countries: Bosnia and Herzegovina, Croatia, France, Hungary, Italy, Serbia, Macedonia, Poland, Russia, Singapore, Spain (Legislationline.org).

What's more, in various countries a different period of election silence has been introduced. In Bulgaria, Slovenia, Hungary, Croatia, Russia and Albania - as in Poland - the election silence starts 24 hours before polling day. In some countries (Czech Republic, Slovakia, Romania (Kryszeń 2007, p. 185) the period of election silence was statutorily extended and begins 48 hours before the vote (Legislationline.org).

It should be noted, that one of the first countries, where election silence was introduced after the world war II, was Germany. The incentive to implement such a solution was a bad experience at the beginning of the interwar period (Kowalczyk, Gmyz, 2009).

As a result of fact that the prohibition of campaigning just before the vote or on voting day, can be seen as a violation of freedom of expression, in many Western democracies regulations regarding election silence are deemed to be unconstitutional.

Summing up, the election silence is functioning with in many so-called young democracies, where the specific limitation of the political debate just before the elections is justified - it is in fact to prevent the escalation of conflicts between the political actors before and during the voting. One should remember, that in many countries, the electoral silence was established by the law (in special legal acts), but in some countries, e.g. in Sweden, there exists a so-called Gentlemen's agreement between the main political forces, which 
commits to conduct their campaigns according to specific standards and to refrain from campaigning within a certain time before the election (Campaign silence...). Very interesting to note is that due to the lack of practice in election silence in Anglo-Saxon countries, the term does not exist in English language, at least, it is not commonly used. The election silence is a completely unknown phenomenon there. According to Mariusz Zawadzki, "if someone tried to impose election silence in America [...] it would raise a general alarm, both on the left and on the right wing, that the person is carrying out an attack on the Sacred First Amendment to the U.S. Constitution, which provides citizens with complete freedom of expression" (Zawadzki 2011). Moreover, in 1992 the Supreme Court in the United States in the case Burson v. Freeman ruled that on the day of voting the conduct of electioneering is only prohibited in the polling station and within a walking distance (100 feet) from it (Burson v. Freeman).

Today, when new technologies develop very rapidly and influence on political life, democracies are prone to different threats related to violating the election silence. It is due to the fact that the election silence functions also in the Internet - it means that no political agitation must be conducted in the cyberspace. But in reality different objects try to impact the electorate and agitate for various politicians, despite the ban. Such actions can not be considered as the official election campaign (because campaigns are run by the election staffs of the candidate), but one can say that the Internet activity of an electioneering (led by individuals) is an attempt to breach the electoral silence.

\section{Election silence in Poland - legal dimension}

The election silence - similarly to other Central and East European Countries - is also functioning in Poland. Various forms of prohibition on political agitation were introduced to electoral laws before 1989 and after the turn of the eighties and nineties, for instance in the Act of $7^{\text {th }}$ April 1989 - the Election Law to the Sejm of the Polish People's Republic of the 10. term, for the years 1989-1993, there was an Article 26 that prohibited campaigning at the polling station on Election Day (Ustawa z dnia 7 kwietnia $1989 \mathrm{r}$. ordynacja..., article 62).

It needs to be pointed out that since $1^{\text {st }}$ August 2011, a new legal act has been in force in Poland - Act of $5^{\text {th }}$ January 2011 - The Election Code (Ustawa z dnia 5 stycznia 2011 r. Kodeks wyborczy...). The law regulates issues related to all types of elections: general elections (Ustawa z dnia 12 kwietnia 2001 r. - Ordynacja wyborcza do Sejmu...), presidential elections (Ustawa z dnia 27 września 1990 r. o wyborze Prezydenta...), local elections (Ustawa z dnia 16 lipca 1998 r. - Ordynacja wyborcza do rad gmin...; Ustawa $z$ dnia 20 czerwca 2002 r. o bezpośrednim wyborze wójta...) and elections to the European Parliament (Ustawa z dnia 23 stycznia 2004 r. - Ordynacja wyborcza do Parlamentu...). Previous laws on elections [were repealed in accordance with Article 10 of the Act on enacting provisions of the law - The Election Code (Ustawa z dnia 5 stycznia 2011 r. Przepisy wprowadzajace ...).

In Article 107 of the 2011 Election Code, electoral silence was established. It means that from the end of the campaign until the end of voting you cannot conduct election campaigning in forms listed in paragraph 1 . In the indicated regulation, the following 
were prohibited: "the convening of meetings, organizing marches and demonstrations, making speeches, distributing leaflets, as well as running campaigning for candidates and lists of candidates in any different way" (Ustawa z dnia 5 stycznia 2011 r. Kodeks wyborczy...). In the following section it was prohibited to do any form of "campaigning at the polling station and in the building where this place is" (Ustawa $z$ dnia 5 stycznia 2011 r. Kodeks wyborczy...).

It is worth noting that the Polish legislator drew a distinction between the electoral agitation, and election campaign. The latter is a concept of a broader meaning and describes a period in which political parties and voters can, with legal effect, do activities related to, among others: creation of the electoral committees, reporting and registration of candidates, collecting funds for the organization of the electoral agitation, that is, efforts to convince and persuade the voters to vote for a specific list of voters or for any particular candidate (Gebethner, 2001).

Thus, electoral agitation, called also "the election battle", is understood as a promotion of slogans and inciting the electorate to vote for a particular committee or for a particular person. The Election Code defines the electoral agitation as "public incitement or encouragement, to vote in a certain way or to vote for a particular election committee candidate" (Ustawa z dnia 5 stycznia 2011 r. Kodeks wyborczy..., article 105). It can be led "from the date of acceptance by a competent authority a notice of the establishment of the electoral committee on principles, in forms and places, specified by regulations in the Code" (Ustawa z dnia 5 stycznia 2011 r. Kodeks wyborczy..., article 105).

Arkadiusz Żukowski points out, that although the terms "electoral agitation" and "election campaigns" are of different meanings, they are often regarded as synonyms (Żukowski, 2004). Grzegorz Kryszeń indicates, that these ambiguities regarding definitions of both terms, may cause conflicts of interpretation of these concepts. They can also cause problems in the application of provisions on compliance with election silence (Kryszeń 2007, p. 186).

In Poland, from the end of the election campaign until the closing of polling stations on a voting day, it is prohibited to run an active electoral agitation. The word "active" at this point is very important as the above-mentioned ban covers activities specified in Article 107 of the Election Code. Electoral committees and candidates do not, however, have the obligation to remove from public places all election materials (billboards, posters, leaflets, etc.) on the day prior to the day of voting. It would rather be technically infeasible. However, according to the standpoint of National Electoral Commission, after the election campaign (that is 24 hours before the election day and on the election day) it is prohibited to move in any vehicle (private or public) with the campaigning materials placed on it. It is understood as an "active" agitation. The user of such a vehicle is required to remove the election materials from the vehicle - both from outside and from the inside. It is worth mentioning that also places of religious cult are included as those, where agitation is forbidden during the election silence (Żukowski, 2004, p. 117; Gebethner, 2001, p. 123).

According to Article 115 of the Election Code during the electoral silence it is forbidden to give pre-election polls results on the predicted voting behavior and election results to the public and the results of election surveys carried out on the voting day (exit polls (Szreder, 2011). Any person who violates this injunction shall be subject to a fine from 
500 thousand to 1 million PLN (Ustawa z dnia 5 stycznia 2011 r. Kodeks wyborczy..., article 500). This regulation is mainly due to the fact that pre-election polls published just before the voting, can significantly influence the final outcome of the election.

\section{The election silence on the Internet - examples from Polish elections}

The Internet, as the most important tool of the civilization development in the modern world (Castells, 2007), contributes to the radical changes in political space. This is evidenced, among others by the emergence of concepts such as electronic democracy (e-democracy) or electronic voting (e-voting). In the context of the subject matter of this text, that is, the electoral silence, there appears a question relating to the legitimacy of the operation of silence in a situation where on the Internet, e.g. on Polish-language web pages located on foreign servers, electoral campaigning can be carried out and foreign portals can announce election surveys results.

Although such operations may be not an attempt to violate (only to avoid) the election silence (Cisza wyborcza na portalu...), they are only examples of possibilities of the impact of election information on the attitudes of the electorate and the final outcome of the vote. In connection with the more and more widespread access to the Internet by Polish society, it is clear that the voters, provided that, they express this desire, can easily find the information that should not be published during the election silence. After all, the essence of the election silence is to provide the voter with a quiet decision making, and this decision should not be burdened with the influence of any publication with election contents. In the era of the Internet, maintaining the election silence seems to be impossible, in any case, certainly very difficult. It is, therefore, worth paying attention to any cases of circumvention of the election silence on the websites.

The application of regulations concerning the election silence in the new media, particularly in the Internet, has been facing great difficulties, especially in recent years related to the dynamic development of information and communication technologies. One of the reasons is the constant progress in the field of social communication techniques which creates innovative, unknown and not-used-before possibilities and methods of influencing views, attitudes and political behavior of voters. In the case of the Internet it should be noted that it gives a scope for abuse in the observance of the election silence, because it is not easy to control by the state bodies the information and expression transmitted and exchanged in the global net, regardless of the time differences and national boundaries. Thus, directives seeking the observance of the election silence seem to be useless (Cisza wyborcza na portalu...).

It should be noted here that the Election Code does not have electoral regulations that would discuss the question of election silence in the broad sense of the new media. The ban on electioneering and publishing surveys relates to all kinds of media, including online media, which are treated as the press (Wyjaśnienia Państwowej Komisji Wyborczej z dnia 18 czerwca 2010 r...). The National Electoral Commission, however, in one of its documents published in 2010 provided guidelines on how to keep silence: "The ban of campaigning during the so-called election silence also includes any Internet activity. It means that even the information which is of agitation nature but was posted online on before mid- 
night of $18^{\text {th }}$ June 2010 [until the end of the election campaign - M. MK] may stay there. During the election silence, the only information that can be posted on the Internet is such which does not have the nature of campaigning for candidates" (Wyjaśnienia Państwowej Komisji Wyborczej z dnia 18 czerwca 2010 r...). This fairly terse wording does not exhaust the possibility related to operations violating electoral silence. Examples of emerging opportunities to circumvent the election silence on the Internet are many.

One of the examples of tempering of the election silence may be placing of posts and comments on blogs post. Politicians in many countries around the world appreciated this method of communication with voters and use their blogs to share their views (not only political ones) and comment on, e.g. current (not only) political events in the country and the world. Many of them comment on the election campaigns, pre-election polls and the election itself.

Polish deputies, similarly to their foreign colleagues more and more frequently make use of the "virtual" way of reaching to the voters. Ryszard Czarnecki (PiS - Law and Justice party), for instance, who is a deputy of the European Parliament (MEP), on the day of the parliamentary elections, that is, October $9^{\text {th }}, 2011$, posted on his blog an entry entitled "The election silence - pure nonsense" with the following content: "Because we have election silence, so not a whisper about the election. Instead of that, I recommend my article on ... the absurdity of the functioning of the election silence, which appeared in the last issue of the weekly 'Gazeta Polska'. It can be purchased in kiosks and Empik stores even during the election silence, though it contains both advertisements of the candidates for the Sejm, as well as interviews with candidates and political articles which are explicitly of election nature. That shows the absurdity of the election silence" R. Czarnecki's cited record should not be regarded as election agitation, but the fact is that the entry became a reason to make comments on it by the readers of the blog, who during the election silence provided comments on the opinion of the MEP. In one of the comments by slawona@poczta.onet.pl it was even suggested that law is broken on Czarnecki's site (Comments on the post: Cisza wyborcza-czysty pure nonsens...).

Whereas, it is often difficult to detect if the author runs election propaganda, it is different when it comes to the Internet users' comments on individual politicians' posts. On blog of Leszek Miller, the former Prime Minister of SLD (the Democratic Left Alliance), the entry dated on September 16 $6^{\text {th }}, 2011$ "Mniej niż zero (Less Than Zero)" during the period of election silence there were comments placed which in an obvious way violated the silence. Just a minute after the end of the election campaign ( $8^{\text {th }}$ October at 00:01), a surfer named " $m$ " encouraged to vote for the SLD party. "Let everybody on this blog vote for SLD!", Another Internet user "komuch" on the pre-election Saturday at 12:42 placed a comment: "Although there is election silence, it does not apply to commies. Vote only for SLD" (Comments on the post: Mniej niz zero...).

The above cases are just examples of election silence violations on weblogs. It is worth noting, that the blogs' owners have the possibility to block the posting comments function, so in order for their sites not to be a place for any kind of political agitation in the forbidden time, they should block the comment option on their posts for a period of election silence.

In this context, it makes sense to pose a question about the enforcement of sanctions for election silence violations. It should be noted that, while it is relatively easy to catch in 
the act one or a few people by identifying the IP address of their computers, hypothetically, if hundreds or thousands of people "got activated" during the election silence typing comments calling for the vote for a particular list, the attempt to bringing them to justice would be extremely difficult and lengthy - almost impossible.

Another example of the election silence violation are conversations in chat rooms or instant messaging such as MSN Messenger or Skype. This is not about online conversations on political preferences and political choices (even encouragement to vote for any particular candidate) among friends, it is about sending agitation materials to a broader group of the Internet users who are not friends. This first activity is not an act of election silence violation, but the latter has to be considered as violation of the electioneering ban. Interestingly, while it would be fairly easy to identify and call to account one person, who would induce to voting for a particular party or candidate, the identification and enforcement of penalties against, for example, several hundred or several thousand Internet users, perhaps would not be difficult, but definitely time consuming.

It should be remembered that the ban on electioneering is in force throughout the country, also on Polish websites (on websites owned by citizens of the Republic of Poland or Polish companies, as well as on Internet portals set on Polish servers). And it is here (the Internet) where problems appear. Whereas the ban on the forums mentioned above is obvious and relatively easy to enforce, it is a bit different with the Websites located on foreign servers. Theoretically, it is possible to upload electioneering content on foreign websites, however, as Krzysztof Lorenc from the National Electoral Office in Warsaw points out: when the "[foreign-M. MK] portal is read in Poland, then the election silence is also in force" (Cisza wyborcza na portalu...).

What's more election silence in Poland - although it is valid for the Polish mass media, it does not apply to the foreign media: televisions, radio stations, press ect. That's why it is very easy to find there information on the results of recent election polls, on who is predicted to be a political winner and loser, or on electorate's preferences. If a voter is living abroad and has a access to those information, they have undoubtedly impact on his (or her) attitudes and his (or her) final political choices. Thus, it is reasonable to ask the question about the meaning of election silence for the Polish people entitled to vote who during elections in Poland stay abroad and are going to participate in elections. As they decide on Polish elections - as the rest of the Polish voters - according to the rules - they should have "quiet" conditions to ponder about a political offer and to make a final electoral decision.

But - as noted - they are a subject to the permanent influence of the information provided for instance on the Internet - on various portals or news bulletins. It is significant to present at least some examples of such an impact. On the "Euronews - International News" site, at 0:33 on $8^{\text {th }}$ October 2011, there was placed a text entitled Election campaign ends in Poland, which provided information on recent pre-election polls, according to which the leading was the Donald Tusk's party PO - Civic Platform (35\% of the respondents' votes), followed by Jarosław Kaczyński's PiS - the Law and Justice - with a 27-percent support, and the third in the ranking Ruch Palikota (Palikot's Movement) with $12.5 \%$ of the vote (Election campaign ends in Poland...). On the same day, on the pre-election Saturday at 16:44, on the same site there appeared an article: Polish Voters get a pre-election campaign break copying the survey results from the previous text, but 
also explaining the nature of election silence, and stating that $20 \%$ of Polish electorate is still undecided as to their decisions (Polish voters get a pre-election ...).

On the German information daily website tagesschau.de, dating October $9^{\text {th }}$, at 0:07 Ludgar Kazimierczak published an article: Premier Tusk rechnet sich gute Chancen aus, in which the journalist noted, that according to TNS OBOP surveys, Liberals have $10 \%$ lead over the Conservatives (Premier Tusk rechnet sich gute...).

Since in many countries of Europe and the whole world the Polish voters have permanent access to election information that constantly appear on the online forums (even during the election silence) it is worth having reflection on the purpose and the meaning of election silence. Voters who reside outside the country and intend to vote abroad (but also those who are in Poland and browse foreign websites), cannot fully experience the election silence, the aim of which is to provide reflection on whom to vote in elections.

It is worth recalling a few more examples of election silence violations, which can be found in social media, which especially in recent years have gained widespread popularity. Examples drawn from the activity of the social media are so interesting, because people make use of them at a convenient time, at different times of day and week, hence the maintenance of election silence may be particularly difficult in this environment (Zając, Batorski, 2011, p. 69). Also the conduct of the election campaign is very difficult to control there.

Although, most of the major internet portals instructed their users on what was not permitted during the election silence, still, as Milada Jędrysik writes, "witty and ingenious Pole can manage without much of a problem." Having prohibited publishing opinion polls, it was invented, that their results would be hidden in the form of ingredients in the recipe for donuts or written in a vegetable code (Jędrysik, 2011). Twitter users exchanged information on results of surveys conducted by OBOP encrypting them as prices per kilos of vegetables ("POry po 32 zt, a PIStacje po 30", czyli...; Żarty z ciszy wyborczej $w$ internecie...).

It should be noted that social media play an increasingly important role as a tool of political communication. In particular, the election campaign conducted in the social media places responsibility on election staff for monitoring the content posted by visitors to the profile of the candidate, and above all, for the observance of election silence by supporters or opponents. Furthermore, "the mixed private-public nature of the social media space makes it difficult to assess whether an individual user's behavior can be classified as a violation of election silence" (Zając, Batorski, 2011, pp. 71-72).

\section{Conclusions}

The Internet as a very important channel of political communication today, is used for purposes of agitation, not only by election committees and candidates, but also by voters themselves and what is more, not only during the campaign itself, but also during the pre-election silence.

It is difficult to talk about election silence on the Internet, because it is the media that is virtually impossible to control. The examples used in this article showed that "traditional" rules of campaigning, used for television, radio, or direct campaign cannot be im- 
posed on the Internet. Therefore, the question relating to the meaning of election silence in the time of new media seems to be even more essential.

The arguments supporting the functioning of pre-election silence as a time to reflect in order to make a possibly most objective decision, become less meaningful, since, regardless of the legal restrictions campaign lasts permanently on the Internet (though much less intensely than during the campaign).

Also punishing Internet users for violating election silence seems to be very problematic. While it is fairly easy to identify individuals who violate electioneering ban just before the election or on election day, it would be more problematic (and definitely long lasting) to punish a bigger number of people. Assuming hypothetically that several thousand students from a university or a group of several thousand voters from a municipality lead discussions on support for individual candidates during election silence on the selected online forum or social network and simultaneously encourage to voting for their favorites, there appears a problem in enforcing penalties for undeniable violations of election silence.

One can take action against those few thousand people (identifying their computers), but it would be virtually impossible to identify Internet users who would use computers in so-called Internet cafes. A situation in which Internet users from abroad would conduct election agitation on the web, would be also complicated.

Both information which promotes election committees and surveys are always within the Internet users' reach. Access to this information is permanent: regardless of whether the survey was published two days before election silence, the day before election silence or a minute before the end of election campaign. As for information on foreign sites, situation is similar; in most cases they provide information about past election polls even on election day, recalling who according to them has a chance of electoral victory.

Thus, answering the question on the usefulness of election silence and validity of its operation, one must admit that, on one hand it can be a useful solution from the voters' perspective, for allowing, in accordance with the idea, a peaceful electoral decision. On the other hand, it should be noted that election Sundays in Poland are quite boring, so voters often are not interested in what is happening in the country, they often forget to vote. It may be due to de lack of political information - that is campaign, which is the result of the election silence.

In the face of the rapid development of the ICT - particularly - the Internet, the issue of election silence can be one of those problems that in the coming years will require clarifying and adjusting to the existing realities. It seems that there is a great need that The politicians should rethink the rational argumentation about positive and negative effects of election silence, and above all, realize the extent to which it does not make sense today. This could motivate them to change the provisions (or part of them) relating to the functioning of election silence, which is difficult to maintain primarily on the Internet.

\section{Literature}

Burson v. Freeman, 504 U.S. 191 (1992) - Charles W. Burson, Attorney General and Reporter for Tennessee, Petitioner v. Mary Rebecca Freeman Certiorari to the Supreme Court of Tennessee, 
No. 90-1056, Argued October 8, 1991, Decided May 26, 1992; FindLaw, http://caselaw.lp. findlaw.com/cgi-bin/getcase.pl?court=us\&vol=504\&invol=191, 2.09.2013.

Campaign silence, The ACE Electoral Knowledge Network, http://aceproject.org/electoral-advice/archive/questions/replies/699408090, 2.09.2013.

Castells M. (2007), Społeczeństwo sieci, PWN, Warszawa.

Cisza wyborcza na portalu Emito.net, 7.10.2011, Emito.net Polski Portal w Wielkiej Brytanii, http://www.emito.net/wiadomosci/wielka_brytania/cisza_wyborcza_na_portalu_emito_net_ 1031720.html, 2.09.2013.

Comments on the post: Cisza wyborcza - czysty pure nonsens, 9.10.2011, Ryszard Czarnecki's Blog, http://ryszardczarnecki.blog.onet.pl/, 5.11.2011.

Comments on the post: Mniej niż zero, 16.10.2011, Leszek Miller. Official political blog, http://leszek-miller.blog.onet.pl/5219167,435826994,1,200,200,89631350,435826994,6596 546,650,forum.html, 5.11.2011.

Digital Democracy: Issues of Theory and Practice (2000), eds. K. L. Hacker, J. Dijk, London.

Election campaign ends in Poland, 8.10.2011, Euronews - International News, http://www.euronews.net/2011/10/08/election-campaigning-ends-in-poland/, 2.09.2013.

Ferdinand P. (2000), The Internet, Democracy and Democratization, Frank Cass, London.

Gebethner S. (2001), Wybory do Sejmu i do Senatu. Komentarz do Ustawy z dnia 12 kwietnia 2001 r. - Ordynacja wyborcza do Sejmu Rzeczypospolitej Polskiej i do Senatu Rzeczypospolitej Polskiej, Warszawa.

Jędrysik M., Kod warzywny, czyli cisza wyborcza w Internecie, 9.10.2011, Gazeta.pl, http://wyborcza.pl/ 1,76842,10439476,Kod_warzywny_czyli_cisza_wyborcza_w_internecie.html, 2.09.2013.

Kanyo Ch. (2012), Promoting E-Democracy and Citizen Participation through ICT Initiatives in Parliament: The Malawi Case, in: E-Parliament and ICT-Based Legislation: Concept, Experiences and Lessons, ed. Mehmet Zahid Sobaci, Hardvcover.

Kowalczuk P., Gmyz C., Cisza wyborcza psuje demokrację?, 6.06.2009, Rzeczpospolita.pl, http://www.rp.pl/artykul/316207.html, 2.09.2013.

Kryszeń G. (2007), Standardy prawne wolnych wyborów parlamentarnych, Temida, Białystok.

Legislationline.org, OSCE Office for Democratic Institutions and Human Rights, ODIHR Documentation Center, http://www.legislationline.org/, 2.09.2013.

Michalak B., Sokala A. (2010), Leksykon prawa wyborczego i systemów wyborczych, Warszawa.

Musiał-Karg M. (2013), Cisza wyborcza w dobie Internetu, "Przegląd Sejmowy", no. 3(116).

Musiał-Karg M. (2013), Cisza wyborcza w internecie - przykład polskich wyborów parlamentarnych z 2011 r., "Studia Politologiczne", no. 27.

Polish voters get a pre-election campaign break, 8.10.2011, Euronews - International News, http://www.euronews.net/2011/10/08/polish-voters-get-a-pre-election-campaign-break/, 2.09.2013.

"POry po 32 zl, a PIStacje po 30", czyli jak na Twitterze omija się ciszę wyborcza, 9.10.2011, Deser.pl, http://deser.pl/deser/1,111858,10438623,_POry_po_32_zl_a_PIStacje_po_30__czyli_jak na_Twitterze.html, 2.09.2013.

Premier Tusk rechnet sich gute Chancen aus, 9.10.2011, Tagesschau.de, http://www.tagesschau.de/ ausland/polen402.html, 2.09.2013.

Szreder M., Emocje i prawda wieczoru wyborczego, 27.09.2011, Rzeczpospolita.pl, http://www.rp.pl/ artykul/9157,723522.html?p=1, 2.09.2013.

Ustawa z dnia 7 kwietnia 1989 r. ordynacja wyborcza do Sejmu Polskiej Rzeczypospolitej Ludowej X kadencji, na lata 1989-1993, Dz. U. 1989, Nr 19, poz. 102, art. 62.

Ustawa z dnia 27 września 1990 r. o wyborze Prezydenta Rzeczypospolitej Polskiej, Dz. U. 1990, $\mathrm{Nr} 67$, poz. 398 z późn. zm. 
Ustawa z dnia 16 lipca 1998 r. - Ordynacja wyborcza do rad gmin, rad powiatów i sejmików województw, Dz. U. 1998, Nr 95, poz. 602 z późn. zm.

Ustawa z dnia 12 kwietnia 2001 r. - Ordynacja wyborcza do Sejmu Rzeczypospolitej Polskiej i do Senatu Rzeczypospolitej Polskiej, Dz. U. 2001, Nr 46, poz. 499 z późn. zm.

Ustawa z dnia 20 czerwca 2002 r. o bezpośrednim wyborze wójta, burmistrza i prezydenta miasta, Dz. U. 2002, Nr 113, poz. 984 z późn. zm.

Ustawa z dnia 23 stycznia 2004 r. - Ordynacja wyborcza do Parlamentu Europejskiego, Dz. U. 2004, $\mathrm{Nr} 25$, poz. 219 z późn. zm.

Ustawa z dnia 5 stycznia 2011 r. Kodeks wyborczy, Dz. U. 2011, Nr 21 poz. 112 [Act of $5^{\text {th }}$ January 2011 - The Election Code, Journal of Laws 31 January, 2011], art. 107.

Ustawa z dnia 5 stycznia 2011 r. Przepisy wprowadzajace ustawe - Kodeks wyborczy, Dz. U. 2011, $\mathrm{Nr} 21$, poz. 113, art. 10.

Wyjaśnienia Państwowej Komisji Wyborczej z dnia 18 czerwca 2010 r. w sprawie tzw. "ciszy wyborczej”, Państwowa Komisja Wyborcza, http://pkw.gov.pl/wyjasnienia-informacje-i-pisma-okolne-pkw-22827/wyjasnienia-panstwowej-komisji-wyborczej-z-dnia-18-czerwca-2010-r-w-sprawie-tzw-ciszy-wyborczej.html, 15.11.2011.

Zając J. M., Batorski D. (eds.), Kampania w sieci, Instytut Spraw Publicznych, Warszawa 2011.

Zawadzki M., W Ameryce o ciszy nie styszeli, 8.10.2011, Gazeta.pl, http://wyborcza.pl/ 2029020,75477,10431487.html, 2.09.2013.

Żarty z ciszy wyborczej w internecie: ziemniaki po 32 zeta..., 10.10.2011, Gazeta.pl, http://www.tokfm.pl/Tokfm/2029020,117303,10440644.html, 2.09.2013.

Żukowski A. (2004), System wyborczy do Sejmu i Senatu RP, Wydawnictwo Sejmowe, Warszawa.

\section{Streszczenie}

\section{Cisza wyborcza we współczesnych demokracjach. Pytania o zasadność funkcjonowania ciszy wyborczej w dobie Internetu}

Technologie komunikacyjne i informacyjne w znacznym stopniu wpływają na instytucje i procedury demokratyczne. Jednym z przykładów takiego wpływu ICT jest cisza wyborcza, która ma na celu umożliwić wyborcom spokojne i wolne agitacji politycznej warunki do podjęcia ostatecznej decyzji co do sposobu głosowania. Pomimo zakazu agitowania w czasie ciszy wyborczej wielu użytkowników Internetu prowadzi kampanię na rzecz konkretnych polityków czy ugrupowań politycznych, naruszając obowiązujące prawo. Głównym celem niniejszego tekstu jest odpowiedź na pytanie o sposoby naruszania ciszy wyborczej w Internecie oraz o zasadność funkcjonowania tego mechanizmu w dobie Internetu. Motywacją do skoncentrowania się na tym problemie było m.in. pojawienie się dużej liczby raportów na temat łamania ciszy wyborczej w Internecie, a w konsekwencji pojawienie się wielu wątpliwości co do utrzymania tego mechanizmu w demokracji.

Słowa kluczowe: cisza wyborcza, Internet, agitacja, kampania, naruszenie ciszy wyborczej 